\title{
Evidence for the validity of Protatlanta sculpta (Gastropoda: Pterotracheoidea)
}

Deborah Wall-Palmer ${ }^{1,2,6}$, Alice K. Burridge ${ }^{2,3}$, Katja T.C.A. Peijnenburg ${ }^{2,3}$, Arie Janssen², Erica Goetze ${ }^{4}$, Richard Kirby $^{5}$, Malcolm B. Hart ${ }^{1}$, Christopher W. Smart ${ }^{1}$

${ }^{1}$ School of Geography, Earth and Environmental Sciences, Plymouth University, Drake Circus, Plymouth, PL4 8AA, United Kingdom

${ }^{2}$ Naturalis Biodiversity Center, P.O. Box 9517, 2300 RA Leiden, the Netherlands

${ }^{3}$ Institute for Biodiversity and Ecosystem Dynamics (IBED), University of Amsterdam, P.O. Box 94248, 1090 GE Amsterdam, the Netherlands

${ }^{4}$ Department of Oceanography, University of Hawai'i at Mānoa, 1000 Pope Road, Honolulu, HI 96822, USA

${ }^{5}$ Marine Biological Association, Citadel Hill, Plymouth, PL1 2PB, United Kingdom

${ }^{6}$ E-mail: deborah.wall-palmer@plymouth.ac.uk

Key words: Atlantic Ocean, biogeography, DNA barcoding, morphometrics, Protatlanta, shelled heteropod

\begin{abstract}
The genus Protatlanta is thought to be monotypic and is part of the Atlantidae, a family of shelled heteropods. These microscopic planktonic gastropods are poorly known, although research on their ecology is now increasing in response to concerns about the effects of ocean acidification on calcareous plankton. A correctly implemented taxonomy of the Atlantidae is fundamental to this progressing field of research and it requires much attention, particularly using integrated molecular and morphological techniques. Here we use DNA barcoding, shell morphology and biogeography to show that the genus Protatlanta includes at least two valid species in the Atlantic Ocean. Protatlanta souleyeti and Protatlanta sculpta were found to be separate species, with different shell morphology and separated by a K2P genetic distance of $19 \%$ sequence divergence at the Cytochrome Oxidase 1 gene. This evidence supports the revival of the species name P. sculpta, which was described by Issel in 1911, but has not been recognised as a valid species since 1915 .
\end{abstract}

\section{Contents}

\begin{tabular}{|c|c|}
\hline Introduction & 423 \\
\hline Taxonomic history of the genus Protatlanta & 424 \\
\hline Material and methods & 425 \\
\hline Morphometric analysis. & 42 \\
\hline DNA barcoding ................... & T. \\
\hline Results and discussion & 427 \\
\hline Shell morphology & 42 \\
\hline DNA barcoding ...... & 43 \\
\hline Biogeography ......... & 43 \\
\hline 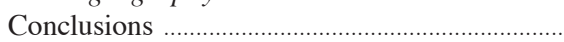 & 43 \\
\hline Acknowledgements & 43 \\
\hline 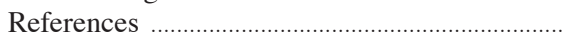 & 43 \\
\hline Appendix ......................... & \\
\hline
\end{tabular}

\section{Introduction}

The genus Protatlanta Tesch, 1908 is one of three shelled heteropod genera within the family Atlantidae. All members of the Atlantidae are microscopic $(<12$ $\mathrm{mm}$ ), holoplanktonic gastropods that have a foot modified for swimming, a long proboscis, large, complex eyes and flattened shells with keels. Defining characteristics of the three genera within the Atlantidae are largely based on shell morphology and shell composition (see Seapy, 1990; Seapy, 2011 for species key). The most diverse genus, Atlanta Lesueur, 1817, contains 19 species (Seapy, 2011) and is characterised by an aragonite shell and keel. The genus Protatlanta is characterised by an aragonite shell with a fine, transparent, conchiolin keel and the genus Oxygyrus Benson, 1835 is characterised by an aragonite juvenile shell, enclosed within adult whorls of conchiolin and a conchiolin keel. Both Protatlanta and Oxygyrus are thought to be monotypic genera, although several extinct species of Protatlanta have been described (Gabb, 1873; Janssen, 2007; Janssen, 2012a, b).

Due to their small size and difficulty to sample and identify, we know very little about the Atlantidae in general (Wall-Palmer et al., 2016) and even less about the genus Protatlanta. Specimen collections and published records show that protatlantids are widespread in the oceans, occurring globally in tropical, subtropical and temperate regions (Fig. 1). Protatlantids can also make up a high proportion of Atlantidae specimens caught in plankton samples, for example, protatlantids made up a total of $29 \%$ of Atlantidae specimens caught 


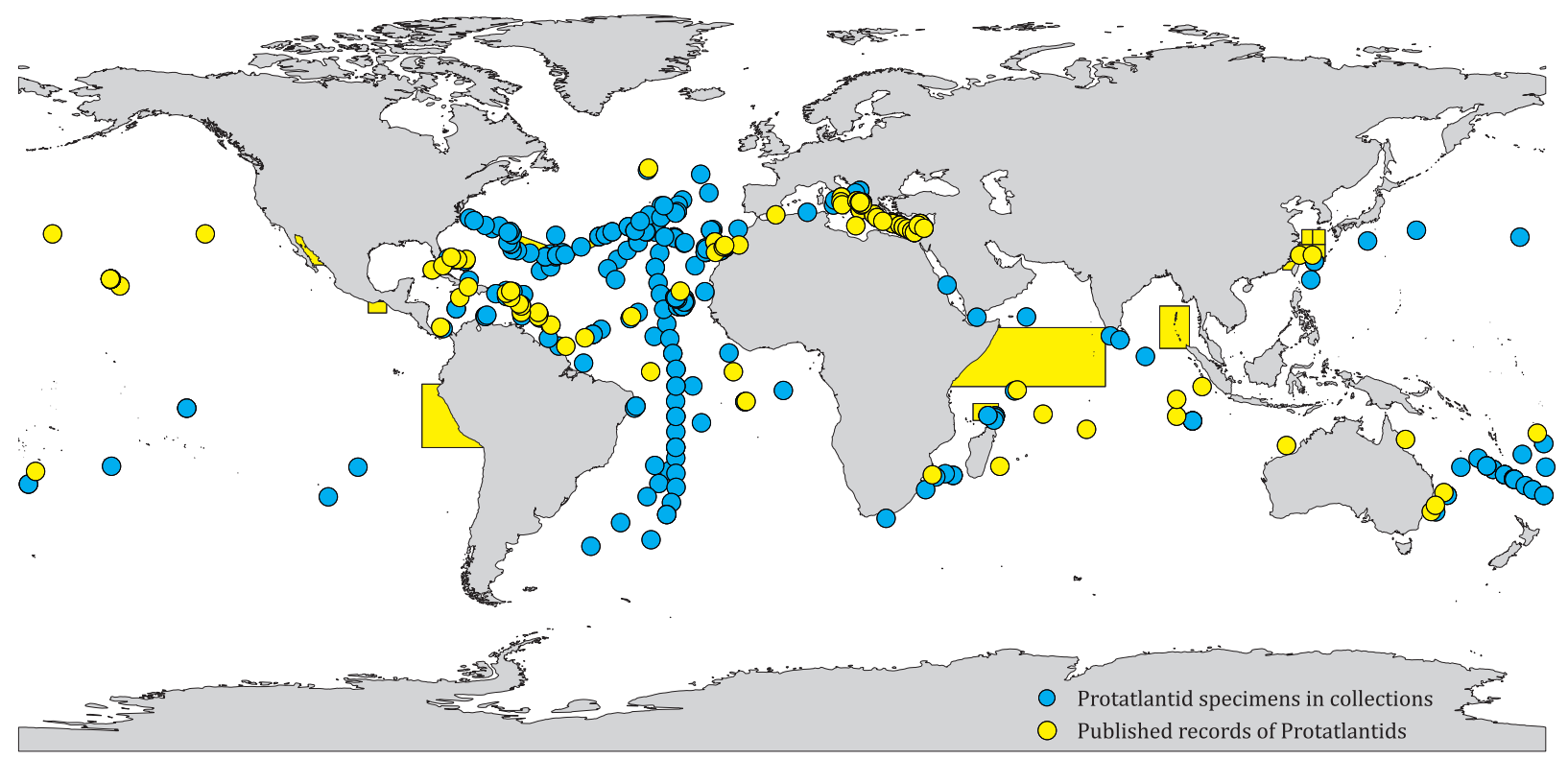

Fig. 1. Biogeography of the genus Protatlanta. Published data (yellow) compiled by Wall-Palmer et al. (2016). Specimens in collections (blue) are from surface sediment and plankton samples stored at the Naturalis Biodiversity Center (Leiden), Natural History Museum (London), Zoological Museum (Copenhagen), VU (Amsterdam) and the Plymouth Marine Laboratory (Plymouth).

in all plankton tows during the Atlantic Meridional Transect cruise in 2014 (AMT24, Burridge et al. in press). There is currently a lot of interest in planktonic gastropods as potential bioindicators of ocean changes, in particular, ocean acidification. However, thus far, the focus of these studies has been on the shelled pteropods (e.g. Bednaršek et al., 2012). Similarities between the thin aragonite shell and surface ocean habitat of the shelled pteropods and the shelled heteropods, means that the Atlantidae are also likely to be vulnerable to ocean acidification and could act as valuable bioindicators.

Despite their wide distribution, relatively high abundance within the planktonic gastropod community and likely threat from global changes, we still know very little about the protatlantids. It is becoming increasingly important to investigate these planktonic organisms, to resolve their species boundaries and to determine their distributions and ecology as a baseline for future research of the effects of ocean changes.

\section{Taxonomic history of the genus Protatlanta}

The first extant species of Protatlanta was introduced by Gray (1850), described from a specimen collected in the Atlantic Ocean. Gray (1850) identified this specimen as Atlanta lamanoni (a homonym of Steira lamanoni Eschscholtz 1825), after a species dubiously illustrated by Lamanon (1797) that is now considered to be a synonym of Atlanta peronii (Janssen, 2012c). Smith (1888) realised that Gray's specimen was not $A$. lamanoni, but a new species and, in the description of specimens from the Challenger expedition, named this new species Atlanta souleyeti. In 1908, Tesch recognised that the conchiolin keel of this species required the introduction of a new intermediate genus between Atlanta and Oxygyrus, thus establishing the genus Protatlanta containing one species, Protatlanta souleyeti. Protatlanta souleyeti is a small species with an aragonite shell of up to $2 \mathrm{~mm}$ in diameter and a conchiolin keel. It is characterised by a rounded, slightly elevated shell spire that has no ornamentation (Smith, 1888; Seapy, 2011).

Issel $(1911,1915)$ described a further species and a variety of Protatlanta, Protatlanta sculpta Issel, 1911 from offshore of the Cape Verde Islands, Atlantic Ocean and Protatlanta sculpta var. mediterranea Issel, 1915 from offshore of Messina, Mediterranean Sea. Issel (1911) described the main features of $P$. sculpta as having a smaller juvenile shell than $P$. souleyeti, with brown colouration. The spire is de- 
scribed as being ornamented with irregular, wavy and frequently interrupted spiral lines, becoming just two lines in the final whorl of the juvenile shell. The final, adult whorl bears no ornamentation. Issel (1911) also suggested that the keel of $P$. sculpta inserts closer to the aperture than in P. souleyeti. Despite the clear morphological features that characterise P. sculpta, the species name $P$. sculpta has not been used since 1915 (Issel, 1915), having been assumed a synonym of $P$. souleyeti since this time. A number of authors have noted this 'second form' of Protatlanta, particularly in the Atlantic Ocean (Batten and Dumont, 1976; Richter and Seapy, 1999; Seapy 2011). Fossil specimens have even been described from the Pliocene of the Philippines (Janssen, 2007), although the name P. sculpta was not used.

Protatlanta sculpta var. mediterranea is described as having generally the same shape and ornamentation as P. sculpta from the Atlantic Ocean, but lacking the brown colouration. Unlike P. sculpta, this variety was recognised as a valid taxon until 1970 (Di Geronimo, 1970). We did not find any specimens matching this description from the Mediterranean Sea or elsewhere during this study. Therefore, we are unable to determine whether this is a valid variety of P. sculpta.

Two extinct species of Protatlanta with shell ornamentation have been described, both from the Miocene fossil record. Protatlanta rotundata (Gabb, 1873) was described from the Miocene of the Dominican Republic and Protatlanta kbiraensis Janssen, 2012b was described from the Langhian (15.97-13.65 Ma, Middle Miocene) of Malta and Italy. Descriptions and illustrations of specimens by Janssen $(2007,2012 a)$ suggest that these species may have had spiral lines on the juvenile shell.

Here we investigate whether the morphological characteristics described by Issel (1911), and identified in specimens from recent plankton sampling, indicate a second species of Protatlanta. A combination of DNA barcoding of the $\mathrm{CO} 1$ gene, morphometrics and biogeography of specimens from the Atlantic Ocean are used to address the original description of P. sculpta to determine whether this species name should be revived. We follow an integrated taxonomic approach, combining molecular and morphological evidence (e.g. McManus and Katz, 2009; Padial et al., 2010), and consider a species to be different when it is genetically distinct and shows corresponding differences in morphological characters.

\section{Material and methods}

Specimens of Protatlanta used for this study were sourced from a number of collections. Fresh specimens for molecular and morphological analysis were collected from the Atlantic Ocean during the Atlantic Meridional Transects AMT24 (N=404, late September to October 2014) and AMT20 (N=68, October to November 2010). Oblique tows were carried out using a CalBOBL bongo net with an aperture diameter of $0.71 \mathrm{~m}$ for AMT24 and a WP2 bongo net with an aperture diameter of 0.57 for AMT20. Both nets had a mesh size of $200 \mu \mathrm{m}$. For sample collection during AMT24, a flowmeter (General Oceanics 2030RC) was mounted at the mouth of one of the nets to measure the volume of water sampled for quantitative analysis (Burridge et al., in press). Specimens from AMT24 were fixed and preserved in $96 \%$ ethanol and stored at $-20^{\circ} \mathrm{C}$ prior to DNA barcoding. Specimens from AMT20 were fixed and stored in 96\% ethanol and stored at room temperature. Storage at room temperature is not optimal for the preservation of DNA, therefore, specimens from AMT20 were not used for DNA barcoding. Station information and sampling parameters for all specimens are given in Table S1.

A total of seven specimens from the recent fossil record $(0-10 \mathrm{ka})$ were used for morphometric analysis. Fossil specimens were collected from a marine sediment core from site CAR-MON 2, offshore of Montserrat, Lesser Antilles (Le Friant et al., 2008; WallPalmer et al., 2014). For the biogeography, additional specimens were examined from the Challenger collection and the National Institute of Oceanography Discovery collection ( $\mathrm{N}=66$, surface sediment and plankton samples Natural History Museum, London), the ACE-ASIA, KH-11-10, VANC10MV and CANCAP Expeditions collections $(\mathrm{N}=100$, plankton samples and surface sediment, Naturalis Biodiversity Center, Leiden), the Dana and Thor collections ( $\mathrm{N}=337$, plankton samples, Zoological Museum, Copenhagen) and the APNAP-I-1986 and G0-Snellius-II collections $(\mathrm{N}=21$, plankton samples, Vrije Universiteit, VU, Amsterdam). Collection information is given in Table S1. All biogeographical data was plotted using the software QGIS (QGIS Development Team, 2016).

\section{Morphometric analysis}

Morphometric analysis was performed on 19 adult specimens from AMT20 and AMT24 and from the recent fossil record of site CAR-MON 2 (Le Friant et al., 


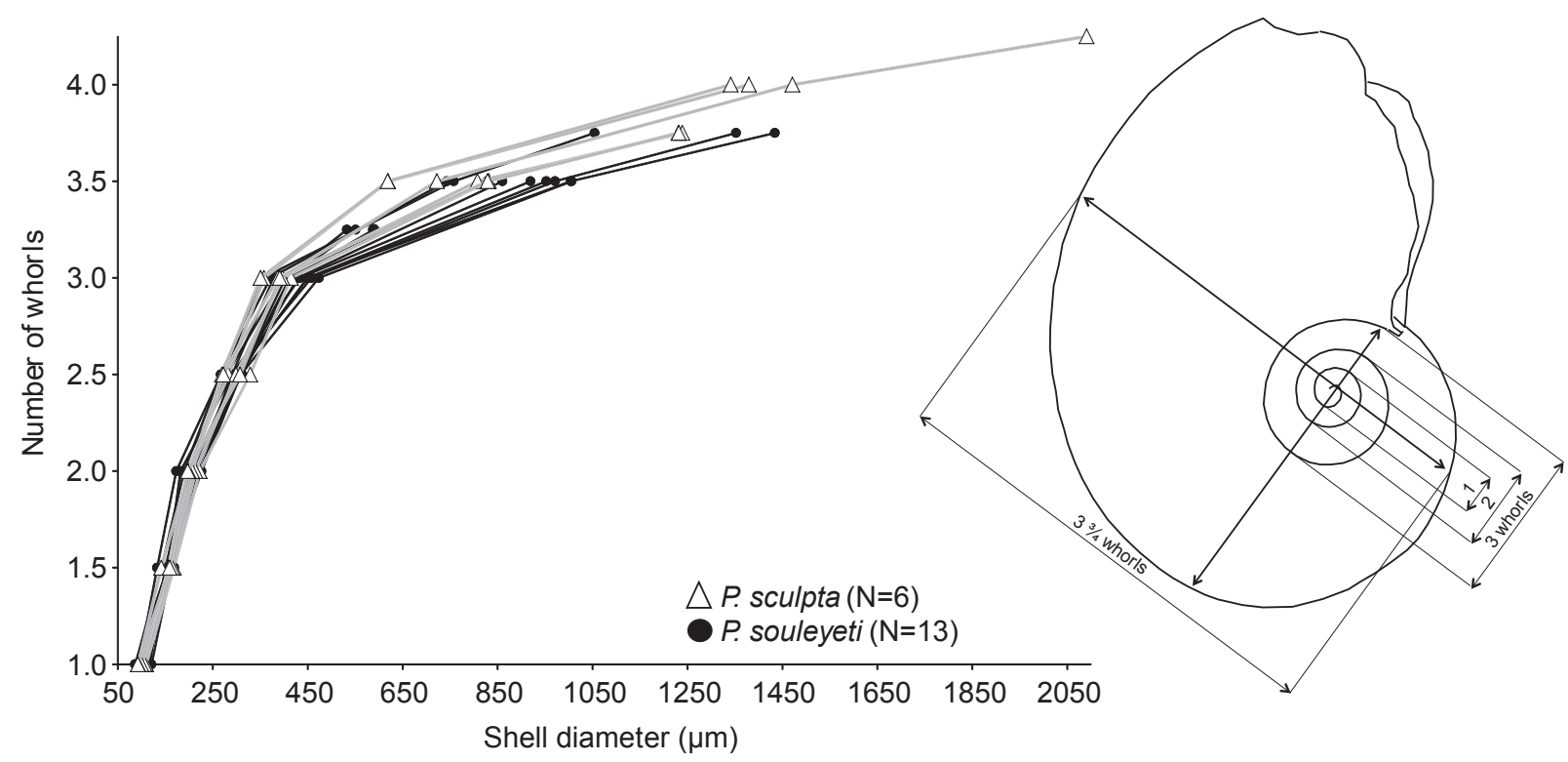

Fig. 2. Method of whorl counting of Protatlanta shells, following the method of whorl numbering by Seapy (1990) and morphometric shell measurements for $P$. souleyeti (black circles, black lines) and P. sculpta (white triangles, grey lines) shells. For specimens analysed, see supplementary Table S1. Specimen used for method schematic is $P$. sculpta from Figure $3 \mathrm{k}$.

2008; Wall-Palmer et al., 2014). Images of the apical side of each shell were obtained using light microscopy and scanning electron microscopy. The ImageJ software FIJI (Schindelin et al., 2012) was used to measure the shell diameter perpendicular to the nucleus of the protoconch (Fig. 2) at half whorl intervals throughout each shell.

\section{DNA barcoding}

A random sample of 18 undamaged adult $(\mathrm{N}=7)$ and juvenile $(\mathrm{N}=11)$ specimens from the Atlantic Ocean were selected from AMT24 samples for DNA barcoding. A mixture of ornamented and non-ornamented specimens of varying colour (brown and white) were analysed. All specimens were imaged prior to analysis using a Zeiss automated z-stage light microscope. DNA extraction was carried out on whole specimens, using the NucleoMag 96 Tissue kit by Macherey-Nagel on a Thermo Scientific KingFisher Flex magnetic bead extraction robot, with a final elution volume of $75 \mu \mathrm{l}$. The standard CO1 barcoding fragment (Hebert et al., 2003) was amplified using primers jgLCO1490 and jgHCO2198 (Geller et al., 2013). Primers were tailed with M13F and M13R for sequencing (Messing, 1983). PCR reactions contained $17.75 \mu \mathrm{l} \mathrm{mQ}, 2.5 \mu 1$ 10x PCR buffer CL, $0.5 \mu 125 \mathrm{mM} \mathrm{MgCl}_{2}, 0.5 \mu 1100 \mathrm{mM}$ BSA, $1.0 \mu 110 \mathrm{mM}$ of each primer, $0.5 \mu 12.5 \mathrm{mM}$ dNTPs and $0.25 \mu \mathrm{l} 5 \mathrm{U}$ Qiagen Taq, with $1.0 \mu \mathrm{l}$ of template DNA, which was diluted 10 or 100 times for some samples. PCR was performed using an initial denaturation step of $180 \mathrm{~s}$ at $94^{\circ} \mathrm{C}$, followed by 40 cycles of $15 \mathrm{~s}$ at $94^{\circ} \mathrm{C}, 30 \mathrm{~s}$ at $50^{\circ} \mathrm{C}$ and $40 \mathrm{~s}$ at $72^{\circ} \mathrm{C}$, and finishing with a final extension of $300 \mathrm{~s}$ at $72^{\circ} \mathrm{C}$ and pause at $12^{\circ} \mathrm{C}$. Sequencing was carried out by Macrogen, Europe.

Sequences were examined and edited in MEGA 6 (Tamura et al., 2013), aligned using Mafft v7 (http:// mafft.cbrc.jp/alignment/server/) and are available from GenBank (Table 1). Additional GenBank CO1 sequences from heteropods identified as Atlanta inclinata, Oxygyrus inflatus, Firoloida desmarestia, Pterotrachea hippocampus and Pterotrachea coronata (Jennings et al., 2010) were used in the analysis to represent the families and genera most closely related to the protatlantids. CO1 sequences of the gastropods Crassitoniella flammea, Pisinna albizona, Bembicium nanum, Echinolittorina riisei, Tectonatica sagraiana, Natica vittata and Ataxocerithium sp. from GenBank (Williams and Reid, 2004; Colgan et al., 2003, 2007; Huelsken et al., 2008; Ayre et al., 2009) were used as outgroups. These all belong to Hypsogastropoda 
Table 1. Station, location and GenBank accession codes for specimens used for DNA barcoding.

\begin{tabular}{|c|c|c|c|c|c|c|}
\hline & $\begin{array}{l}\text { Institute accession } \\
\text { number }\end{array}$ & $\begin{array}{l}\text { Juvenile } \\
\text { or adult? }\end{array}$ & Station & Latitude & Longitude & $\begin{array}{l}\text { Genbank } \\
\text { accession code }\end{array}$ \\
\hline \multirow[t]{10}{*}{ Protatlanta souleyeti } & Psou_AMT24_06_01 & A & AMT24_06 & $31.30^{\circ} \mathrm{N}$ & $27.73^{\circ} \mathrm{W}$ & KU841493 \\
\hline & Psou_AMT24_06_02 & $\mathrm{J}$ & AMT24_06 & $31.30^{\circ} \mathrm{N}$ & $27.73^{\circ} \mathrm{W}$ & KU841494 \\
\hline & Psou_AMT24_06_03 & $\mathrm{J}$ & AMT24_06 & $31.30^{\circ} \mathrm{N}$ & $27.73^{\circ} \mathrm{W}$ & KU841495 \\
\hline & Psou_AMT24_06_04 & A & AMT24_06 & $31.30^{\circ} \mathrm{N}$ & $27.73^{\circ} \mathrm{W}$ & KU841496 \\
\hline & Psou_AMT24_06_05 & $\mathrm{J}$ & AMT24_06 & $31.30^{\circ} \mathrm{N}$ & $27.73^{\circ} \mathrm{W}$ & KU841497 \\
\hline & Psou_AMT24_18_01 & $\mathrm{J}$ & AMT24_18 & $11.95^{\circ} \mathrm{S}$ & $27.02^{\circ} \mathrm{W}$ & KU841500 \\
\hline & Psou_AMT24_19_01 & A & AMT24_19 & $14.66^{\circ} \mathrm{S}$ & $25.07^{\circ} \mathrm{W}$ & KU841501 \\
\hline & Psou_AMT24_19_02 & A & AMT24_19 & $14.66^{\circ} \mathrm{S}$ & $25.07^{\circ} \mathrm{W}$ & KU841502 \\
\hline & Psou_AMT24_23_01 & A & AMT24_23 & $27.76^{\circ} \mathrm{S}$ & $25.01^{\circ} \mathrm{W}$ & KU841506 \\
\hline & Psou_AMT24_25A__01 & A & AMT24_25A & $34.18^{\circ} \mathrm{S}$ & $27.21^{\circ} \mathrm{W}$ & KU841507 \\
\hline \multirow[t]{8}{*}{ Protatlanta sculpta } & Pscu_AMT24_09_01 & $\mathrm{J}$ & AMT24_09 & $20.45^{\circ} \mathrm{N}$ & $29.27^{\circ} \mathrm{W}$ & KU841485 \\
\hline & Pscu_AMT24_09_02 & $\mathrm{J}$ & AMT24_09 & $20.45^{\circ} \mathrm{N}$ & $29.27^{\circ} \mathrm{W}$ & KU841486 \\
\hline & Pscu_AMT24_09_03 & $\mathrm{J}$ & AMT24_09 & $20.45^{\circ} \mathrm{N}$ & $29.27^{\circ} \mathrm{W}$ & KU841487 \\
\hline & Pscu_AMT24_10_01 & $\mathrm{J}$ & AMT24_10 & $18.80^{\circ} \mathrm{N}$ & $31.42^{\circ} \mathrm{W}$ & KU841488 \\
\hline & Pscu_AMT24_16_01 & $\mathrm{J}$ & AMT24_16 & $3.89^{\circ} \mathrm{S}$ & $25.03^{\circ} \mathrm{W}$ & KU841489 \\
\hline & Pscu_AMT24_16_02 & $\mathrm{J}$ & AMT24_16 & $3.89^{\circ} \mathrm{S}$ & $25.03^{\circ} \mathrm{W}$ & KU841490 \\
\hline & Pscu_AMT24_16_03 & $\mathrm{J}$ & AMT24_16 & $3.89^{\circ} \mathrm{S}$ & $25.03^{\circ} \mathrm{W}$ & KU841491 \\
\hline & Pscu_AMT24_25_01 & A & AMT24_25 & $34.18^{\circ} \mathrm{S}$ & $27.22^{\circ} \mathrm{W}$ & KU841492 \\
\hline
\end{tabular}

(within Caenogastropoda), supposedly closely related to the heteropods, as suggested by Jennings et al. (2010). A maximum-likelihood tree was constructed based on these data using nucleotide sequences and a General Time Reversible model with different rates at the three codon positions $(+\mathrm{CP})$ model with 1000 bootstraps in RAxML (Stamatakis, 2014). Kimura2-parameter (K2P) genetic distances were calculated between and within species belonging to the family Atlantidae using MEGA 6 (Tamura et al., 2013).

\section{Results and discussion}

\section{Shell morphology}

Two clear groups of Protatlanta were identified: ornamented specimens that are comparable to P. sculpta, as described by Issel (1911) and non-ornamented specimens that follow the description of $P$. souleyeti. The differences in shell ornamentation are most obvious in juvenile specimens (Fig. 3a-d). Non-ornamented specimens have completely smooth shells with no ornamentation (Fig. 3a-b, i-j), whereas ornamented specimens have several spiral lines (Fig. 3c-d). The main spiral lines of ornamented specimens begin on the apical side of the shell at the second whorl as irregular, interrupted spiral lines and become more regular lines in the third whorl (Fig. 3c-d). A third, main spiral line is present and visible in apertural view in juvenile shells, but it is covered by subsequent whorls, so that it is not visible in the adult form (Fig. 3d, 31). This ornamentation is clearly visible with light microscopy, however, scanning electron microscopy reveals additional, finer details, including lines of pores and multiple finer spiral lines in the transition from juvenile to adult whorl (Fig. 3c-d). The final, adult whorl of ornamented specimens does not have any surface ornamentation (Fig. 3h, 3k) and is identical to that of nonornamented specimens. Here, we present the results of this study as comparisons between these two, potentially different species.

The morphometric analysis of 19 adult protatlantid shells reveals that both ornamented $(\mathrm{N}=6)$ and non-ornamented $(\mathrm{N}=13)$ specimens show a similar pattern of shell diameter per whorl, with greater variation in diameter with increasing whorl number for both species (Fig. 2). Adult ornamented specimens (3 $3 / 4$ to $4 \frac{1 / 4}{4}$ whorls) were often $1 / 4$ to $3 / 4$ of a whorl larger than nonornamented specimens ( $3 \frac{1}{2} 2$ whorls). However, two larger non-ornamented specimens were found with $3 \frac{3}{4}$ whorls. In general, ornamented shells begin to inflate rapidly at 3 whorls whereas non-ornamented shells begin to inflate rapidly at $2 \frac{1}{2}$ to 3 whorls (Table 2 ). 


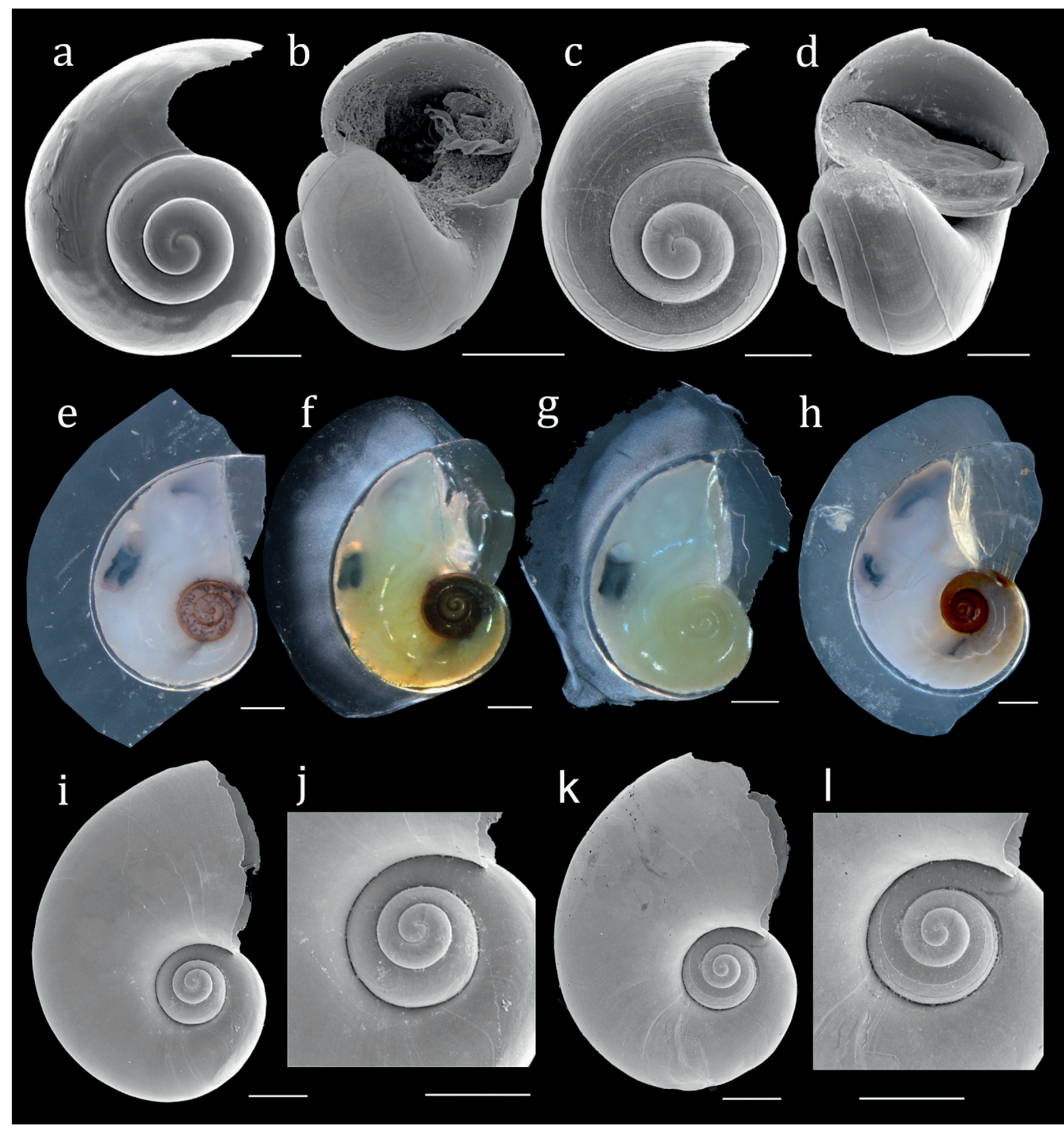

Fig. 3. SEM and light microscope images demonstrating the variation in shell colouration and ornamentation in Protatlanta, a-b) $P$. souleyeti juvenile, c-d) P. sculpta juvenile, e-g) P. souleyeti adult, h) $P$. sculpta adult, i-j) P. souleyeti adult, k-1) $P$. sculpta adult. Scale bars are $100 \mu \mathrm{m}$ for e-1,200 $\mu \mathrm{m}$ for a-d.

Based on these data, we suggest that shell diameter per whorl cannot be used as a diagnostic feature to separate the two groups of Protatlanta. These data also show that, contrary to Issel's (1911) description, specimens with ornamentation do not have a smaller juvenile shell than specimens without ornamentation. In the Atlantic Ocean, specimens of both groups are, in fact, almost identical in size and proportions. It is also apparent that specimen colour cannot be used as a feature to characterise the two groups (Table 2). In 


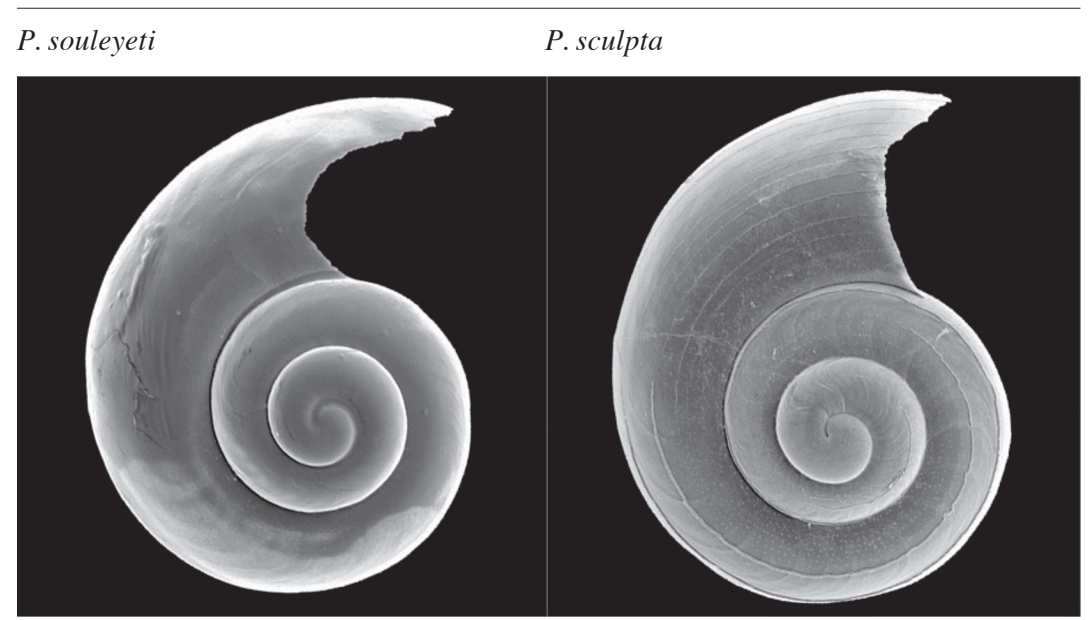

$2 \frac{1}{2}-3$ whorls in spire

$3 \frac{1}{2}-3 \frac{3}{4}$ whorls in adult shell

Spire diameter $350 \mu \mathrm{m}$

Adult shell diameter $<2 \mathrm{~mm}$

No shell ornamentation

Soft tissues within the spire vary in colour from white to dark brown.

Global distribution. Preference for oligotrophic gyres in Atlantic Ocean.

Latitude range $47^{\circ} \mathrm{N}$ to $40^{\circ} \mathrm{S}$
3 - 31/4 whorls in spire

$33 / 4-41 / 4$ whorls in adult shell

Spire diameter $350 \mu \mathrm{m}$

$$
\text { Adult shell diameter }<2 \mathrm{~mm}
$$

Spire surface ornamented with three spiral lines. Adult whorl no ornamentation.

The soft tissues and shell of the spire are brown.

Distribution probably restricted to Atlantic Ocean. Preference for regions outside of oligotrophic gyres.
Table 2. Comparison summary of $P$. souleyeti and P. sculpta.

Table 3. Average K2P pairwise genetic distance of Cytochrome Oxidase 1 sequences for P. souleyeti, P. sculpta and representatives of the genera Atlanta and Oxygyrus.

\begin{tabular}{lllll}
\hline & P. souleyeti & P. sculpta & A. inclinata & O. inflatus \\
\hline P. souleyeti $(\mathrm{N}=10)$ & 0.00 & & & \\
$P$. sculpta $(\mathrm{N}=8)$ & 0.19 & 0.00 & 0.00 & 0.00 \\
A. inclinata $(\mathrm{N}=2)$ & 0.20 & 0.20 & 0.24 & \\
O. inflatus $(\mathrm{N}=2)$ & 0.24 & 0.24 & \\
\hline
\end{tabular}

agreement with the original description of $P$. sculpta by Issel (1911), ornamented specimens were found to always have a brown colouration of the shell in the first $2 \frac{1}{2}$ to 3 whorls (Fig. 3 ). This colouration is sometimes very faint in juvenile specimens, being restricted to the whorl sutures, but becomes darker in adult specimens, emphasised by brown-coloured soft tissues. Non-ornamented specimens have a colourless shell, but the colour of soft tissues can be seen, ranging from white to mottled yellow-brown or dark brown (Fig. 3). This 


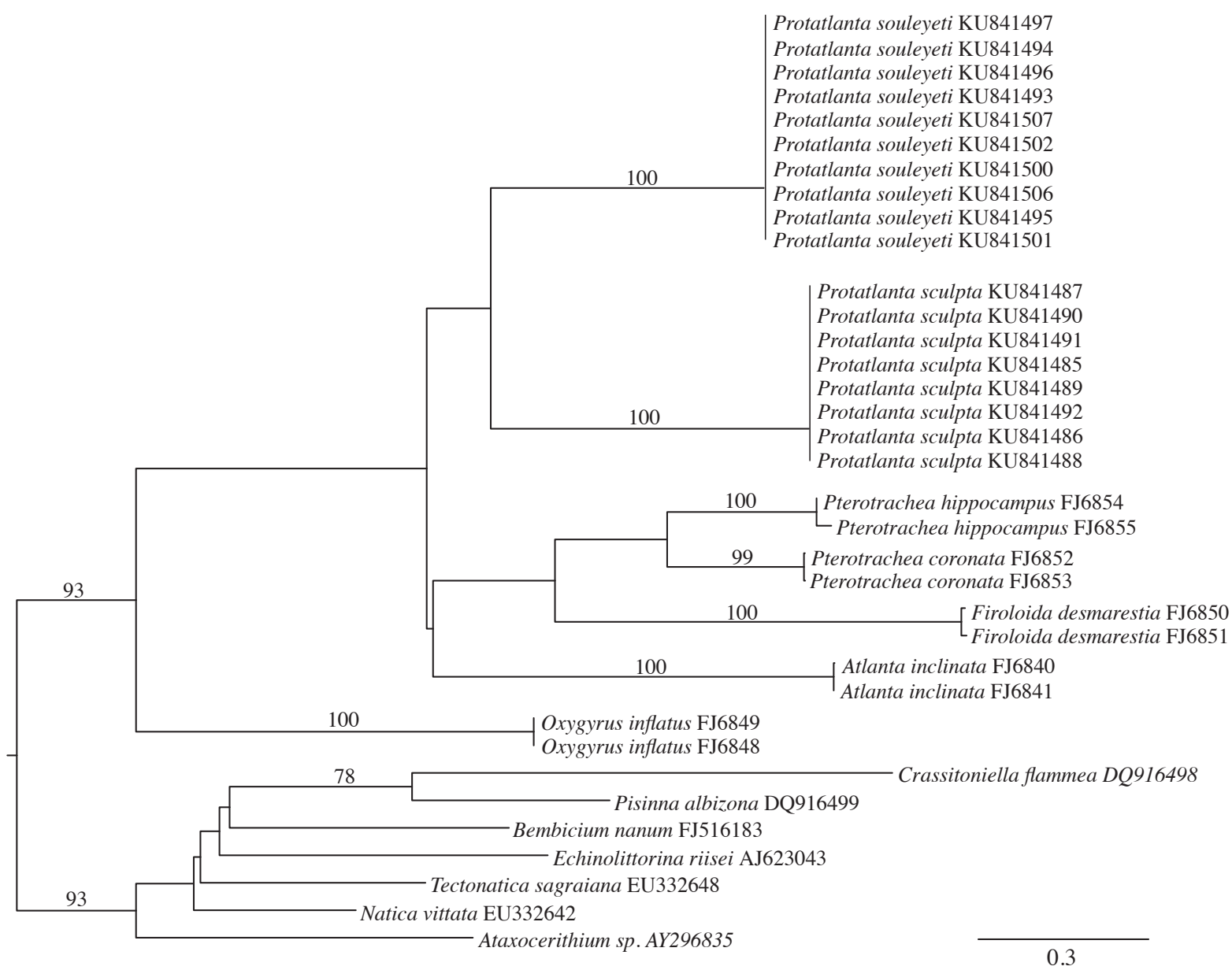

Fig. 4. Maximum-likelihood tree showing relationships based on Cytochrome Oxidase 1 DNA sequences of Protatlanta and other heteropod genera, including several Hypsogastropoda outgroups (see text for more details). Branch lengths are proportional to the amount of inferred change, indicated by the scale bar. Only bootstrap supports (1000 replicates) above $70 \%$ are displayed. GenBank accession codes are presented in Table 1. Sequences from Jennings et al. (2010) begin with FJ, other outgroup sequences are from GenBank.

variation in soft-tissue colour of non-ornamented specimens showed no geographical pattern.

\section{DNA barcoding}

DNA barcoding of 18 specimens of Protatlanta from the Atlantic Ocean revealed two monophyletic clades of Protatlanta with maximum bootstrap support (Figs $4,5)$. The first clade consists of non-ornamented specimens $(\mathrm{N}=10)$, representing the species $P$. souleyeti. The second clade is exclusively made up of ornamented specimens $(\mathrm{N}=8)$. The ornamentation on these specimens is comparable to $P$. sculpta, as described by
Issel (1911) and we therefore consider this second clade to be a separate species, P. sculpta. The average K2P pairwise distance (Table 3) between P. sculpta and $P$. souleyeti is 0.19 . Average $\mathrm{K} 2 \mathrm{P}$ pairwise distances show that the family Atlantidae overall, is highly diversified based on the $\mathrm{CO} 1$ gene. Representatives of the other Atlantidae genera Atlanta and Oxygyrus showed an average pairwise distance of 0.20 and 0.24 from $P$. souleyeti and 0.20 and 0.24 from P. sculpta, respectively. This molecular analysis supports that $P$. sculpta is a valid species and that shell ornamentation is an effective way to identify $P$. sculpta from $P$. souleyeti. 

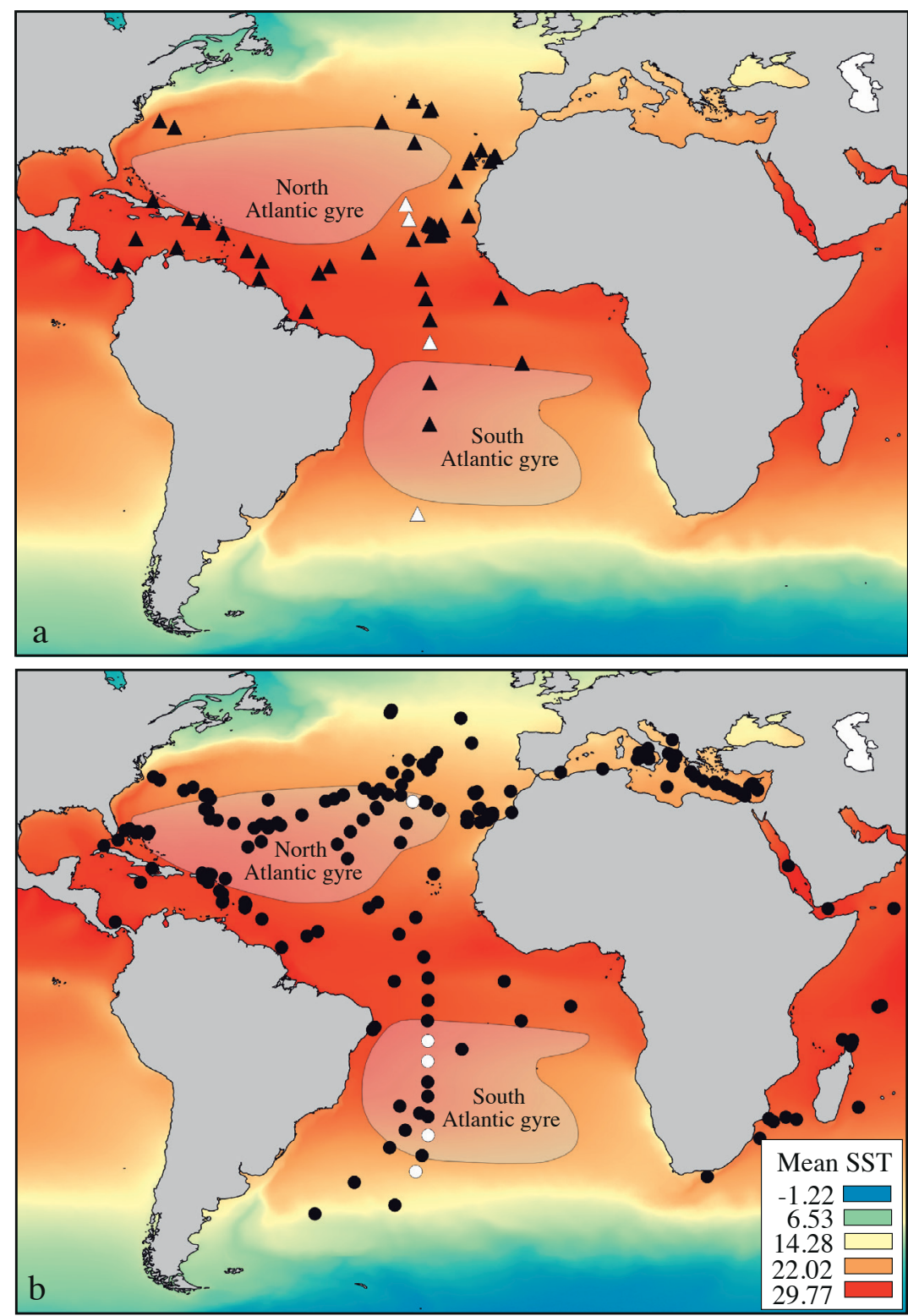

$\triangle$ P. sculpta $\triangle$ P. sculpta DNA barcoded specimens

P. souleyeti $\bigcirc$. souleyeti DNA barcoded specimens
Fig. 5. Protatlanta biogeography in the Atlantic Ocean (a) occurrences of $P$. sculpta (in black) showing stations included in DNA barcoding (in white) and (b) occurrences of P. souleyeti (in black) showing stations included in DNA barcoding (in white). Average sea surface temperature from Tyberghein et al. (2012).

\section{Biogeography}

All specimens of Protatlanta (Table S1) were assessed for shell ornamentation. Following the results of this study, specimens with shell ornamentation were identified as P. sculpta and non-ornamented specimens were identified as $P$. souleyeti (Fig. 5). These specimens $(\mathrm{N}=1003)$ indicate that $P$. sculpta is distributed throughout the Atlantic (Fig. 5a). However, quantita- tive sampling along the meridional transect of AMT24 shows that $P$. sculpta is rarely found within the subtropical gyres, being most abundant in the equatorial upwelling region (Figs 5a, 6). Conversely, quantitative sampling shows that $P$. souleyeti, although widespread in the Atlantic Ocean, has a preference for the northern and southern oligotrophic subtropical gyres (Figs $5 \mathrm{~b}, 6)$. This suggests that the two species have different ecological preferences, with $P$. souleyeti preferring 


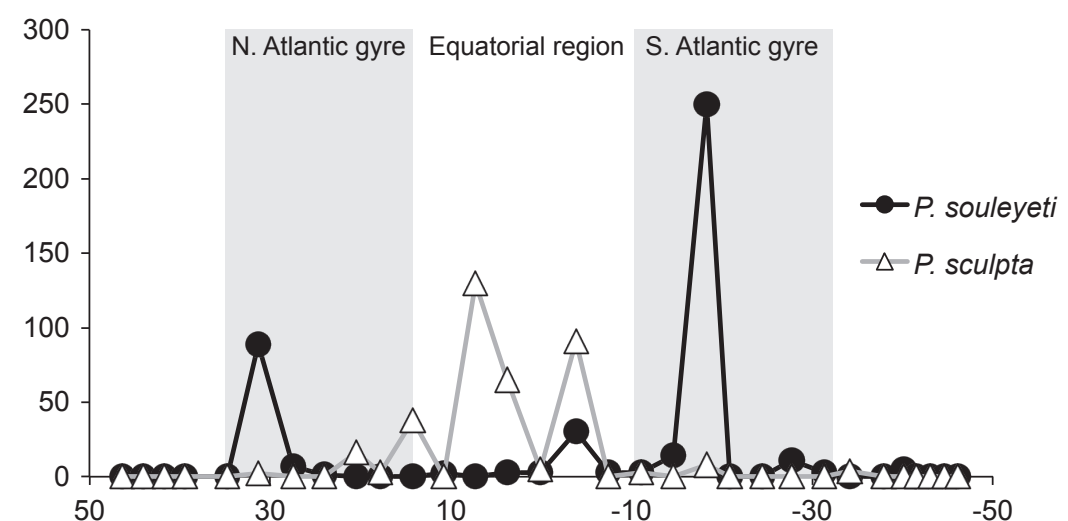

Fig. 6. Abundance (specimens per 1000 $\mathrm{m}^{3}$ ) of P. souleyeti (black circles, black lines) and P. sculpta (white triangles, grey lines) along the AMT24 meridional transect sampled in 2014. Specimens sorted from $25 \%$ or $50 \%$ of the quantitative zooplankton sample depending on bulk sample volumes. oligotrophic regions and P. sculpta preferring more nutrient rich waters.

Samples from the Indian and Pacific oceans permitted initial investigation of the wider distribution of these two species. Specimens of $P$. souleyeti were found worldwide, however, only a single specimen of P. sculpta was found outside of the Atlantic Ocean. This single specimen of P. sculpta (ZMUC_GAS_782) was collected in the Marquesas Islands and a specimen of $P$. souleyeti was collected at the same site.

\section{Conclusions}

Based on the combination of molecular, morphological and biogeographical data presented here, we conclude that there are at least two, valid, extant species of Protatlanta in the Atlantic Ocean, $P$. souleyeti and $P$. sculpta. DNA barcoding of the $\mathrm{CO} 1$ gene supports differences in shell morphology, verifying that $P$. souleyeti and P. sculpta are separate species. The ability to use shell ornamentation to identify between the two species of Protatlanta ensures that they can be identified in sea floor sediments, in plankton samples and in the fossil record, where P. sculpta is known from the Pliocene (Piacenzian).

Biogeographical data have revealed that $P$. souleyet $i$ and P. sculpta inhabit different oceanographic provinces in the Atlantic Ocean and are, therefore, ecologically differentiated. Initial analysis of sites from the Indian and Pacific oceans shows that $P$. souleyeti is found worldwide, whereas $P$. sculpta may be restricted to the Atlantic Ocean.

Aragonite shelled holoplanktonic gastropods (thecosome pteropods and Atlantidae heteropods) are con- sidered to be threatened by, and important bioindicators of, ocean acidification. However, for many species we still do not have an adequate understanding of their species boundaries and biogeography, which is essential to recognise where to monitor for potential changes and what constitutes significant changes in species distribution. This study demonstrates that using an integrative taxonomic approach to reveal species boundaries is an important step in ensuring accurate species identification, which is crucial to understanding species distribution patterns.

\section{Acknowledgements}

We would like to thank Andreia Salvador and Jon Ablett from the Natural History Museum (London), Jeroen Goud and Bram van der Bijl from the Naturalis Biodiversity Center (Leiden), Tom Schiøtte and Martin Vinther Sørensen from the Zoological Museum (Copenhagen), Brett Metcalfe and Gerald Ganssen from Vrije Universiteit (Amsterdam), Atushi Tsuda from the University of Tokyo and Rachel Harmer from the Plymouth Marine Laboratory (Plymouth) for allowing access to Atlantidae collections. We would also like to thank Aline Nieman, Kevin Beentjes and Frank Stokvis (Naturalis) for help with DNA barcoding of specimens and Rachel Harmer (Plymouth Marine Laboratory) for plankton collection on cruise AMT20. We would like to acknowledge the scientists and crew who took part in cruises ACE-ASIA, KH-11-10, AMT20 and AMT24, and the Atlantic Meridional Transect (AMT) programme. This study is a contribution to the international IMBER project and was supported by the UK Natural Environment Research Council National Capability funding to Plymouth Marine Laboratory and the National Oceanography Centre, Southampton. This is contribution number 299 of the AMT programme. We would like to acknowledge the Plymouth Electron Microscopy Centre for help with SEM imaging. We are extremely grateful to Rosie Oakes and four anonymous reviewers for their detailed and constructive comments on our manuscript. This research was 
carried out with funding from the Leverhulme Trust (RPG2013-363, 2014-2017, DW-P, CWS, RK) and a Martin-Fellowship from Naturalis Biodiversity Center (DW-P).

\section{References}

Ayre DJ, Minchinton TE, Perrin C. 2009. Does life history predict past and current connectivity for rocky intertidal invertebrates across a marine biogeographic barrier? Molecular Ecology 18: 1887-1903.

Batten RL, Dumont MP. 1976. Shell ultrastructure of the Atlantidae (Heteropoda, Mesogastropoda) Oxygyrus and Protatlanta, with comments on Atlanta inclinata. Bulletin of the American Museum of Natural History 157: 267-310.

Bednaršek N, Tarling GA, Bakker DCE, Fielding S, Jones EM, Venables HJ, Ward P, Kuzirian A, Lézé B, Feely RA, Murphy EJ. 2012. Extensive dissolution of live pteropods in the Southern Ocean. Nature Geoscience 5: 881-885.

Burridge AK, Goetze E, Wall-Palmer D, Le Double S, Huisman J, Peijnenburg KTCA. In press. Epipelagic distribution of planktic gastropods along a meridional transect in the Atlantic Ocean. Progress in Oceanography.

Colgan DJ, Ponder WF, Beacham E, Macaranas J. 2007. Molecular phylogenetics of Caenogastropoda (Gastropoda: Mollusca). Molecular Phylogenetics and Evolution 42: 717 737.

Colgan DJ, Ponder WF, Beacham E, Macaranas JM. 2003. Molecular phylogenetic studies of Gastropoda based on six gene segments representing coding or non-coding and mitochondrial or nuclear DNA. Molluscan Research 23: 159178.

Di Geronimo I. 1970. Heteropoda e Pteropoda Thecosomata in sedimenti abisali recenti dello Ionio. Thalassia Salentina 4 41-115.

Gabb WM. 1873. On the topography and geology of Santo Domingo. Transactions of the American Philosophical Society New Series 15: 49-259.

Geller J, Meyer C, Parker M, Hawk H. 2013. Redesign of PCR primers for mitochondrial cytochrome c oxidase subunit I for marine invertebrates and application in all-taxa biotic surveys. Molecular Ecology Resources 13: 851-861.

Hebert PD, Cywinska A, Ball SL. 2003. Biological identifications through DNA barcodes. Proceedings of the Royal Society of London. Series B: Biological Sciences 270: 313-321.

Huelsken T, Marek C, Schreiber S, Schmidt I, Hollmann M. 2008. The Naticidae (Mollusca: Gastropoda) of Giglio Island (Tuscany, Italy): Shell characters, live animals, and a molecular analysis of egg masses. Zootaxa 1770: 1-40.

Issel R. 1911. Molluschi Eteropodi raccolti dal Capitano G. Chierchia durante il viaggio di circumnavigazione della $\mathrm{R}$. Nave Vettor Pisani negli anni 18182-83-84-85. Annuario del Museo Zoologico della R. Università di Napoli, Nuova Serie 3: 1-11.

Issel R. 1915. Atlantidae e Carinaria. Memorie R. Comitato Talassografico Italiano, Memoria LII: 3-26.

Janssen AW. 2007. Holoplanktonic Mollusca (Gastropoda: Pterotracheoidea, Janthinoidea, Thecosomata and Gymnosomata) from the Pliocene of Pangasinan (Luzon, Philippines). Scripta Geologica 135: 29-144.

Janssen AW. 2012a. Early Pliocene heteropods and pteropods
(Mollusca, Gastropoda) from Le Puget-sur-Argens (Var), France. Cainozoic Research 9: 145-187.

Janssen AW. 2012b. Systematics and biostratigraphy of holoplanktonic Mollusca from the Oligo-Miocene of the Maltese Archipelago. Bollettino del Museo Regionale di Scienze Naturali, Torino 28: 197-601.

Janssen AW. 2012c. Late Quaternary to Recent holoplanktonic Mollusca (Gastropoda) from bottom samples of the eastern Mediterranean Sea: systematics, morphology. Bollettino Malacologico 48: supplemento: 1-105.

Jennings RM, Bucklin A, Ossenbrügger H, Hopcroft RR. 2010. Species diversity of planktonic gastropods (Pteropoda and Heteropoda) from six ocean regions based on DNA barcode analysis. Deep-Sea Research 57: 2199-2210.

Lamanon [JHR de P de]. 1797. Mémoire sur les cornes d'ammon, et description d'une espèce trouvée entre les tropiques dans la mer du sud. Pp. 134-139 in: Milet-Mureau, MLA. ed, Voyage de la Pérouse autour du monde. Vol. 4. Imprimerie de la République, France.

Le Friant A, Lock EJ, Hart MB, Boudon G, Sparks RSJ, Leng MJ, Smart CW, Komorowski J-C, Deplus C, Fisher JK. 2008. Late Pleistocene tephrochronology of marine sediments adjacent to Montserrat, Lesser Antilles volcanic arc. Journal of the Geological Society, London 165: 279-289.

McManus GC, Katz LA. 2009. Molecular and morphological methods for identifying plankton: what makes a successful marriage? Journal of Plankton Research 31: 1119-1129.

Messing J. 1983. New M13 vectors for cloning. Methods in Enzymology 101: 20-78.

Newman LJ. 1990. The taxonomy, distribution and biology of Atlanta gaudichaudi Souleyet, 1952 (Gastropoda, Heteropoda) from the Great Barrier Reef, Australia. American Malacological Bulletin 8: 85-94.

Padial JM, Miralles A, De la Riva I, Vences M. 2010. The integrative future of taxonomy. Frontiers in Zoology 7: 16.

QGIS Development Team. 2016. QGIS Geographical Information System. Open Source Geospatial Foundation Project. http://qgis.osgeo.org

Richter G, Seapy RS. 1999. Heteropoda. Pp. 621-647 in: Boltovskoy D, ed, South Atlantic zooplankton. Backhuys Publishers, Leiden.

Schindelin J, Arganda-Carreras I, Frise E, Kaynig V, Longair M, Pietzsch T, Preibisch S, Rueden C, Saalfeld S, Schmid B, Tinevez J-Y, Whaite DJ, Hartenstein V, Eliceiri K, Tomancak P, Cardona A. 2012. Fiji: an opensource platform for biological-image analysis, Nature Methods 9: 676-682.

Seapy RR. 2011. Atlantidae. Available at http://tolweb.org/Atlantidae accessed 22nd July 2015.

Seapy RR. 1990. The pelagic family Atlantidae (Gastropoda: Heteropoda) from Hawaiian waters: a faunistic survey. Malacologia 32: 107-130.

Smith EA. 1888. Report on the Heteropoda collected by HMS Challenger during the years 1873-1876. Challenger Reports, Zoology 23: 1-51.

Stamatakis A. 2014. RAxML Version 8: A tool for Phylogenetic Analysis and Post-Analysis of Large Phylogenies. Bioinformatics 30: 1312-1313.

Tamura K, Stecher G, Peterson D, Filipski A, Kumar S. 2013. MEGA6: molecular evolutionary genetics analysis version 6.0. Molecular Biology and Evolution 30: 2725-2729.

Tyberghein L, Verbruggen H, Pauly K, Troupin C, Mineur F, De 
Clerck O. 2012. Bio-ORACLE: a global environmental dataset for marine species distribution modelling. Global Ecology and Biogeography 21: 272-81.

Tesch JJ. 1908. Systematic monograph of the Atlantidae (Heteropoda) with enumeration of the species in the Leyden museum. Notes from the Leyden Museum 30: 1-30.

Wall-Palmer, D., Smart, C.W., Hart, M.B., Leng, M.L., Borghini, M., Manini, E., Aliani, S., Conversi, A. 2014. Late Pleistocene pteropods, heteropods and planktonic foraminifera from the Caribbean Sea, Mediterranean Sea and Indian Ocean. Micropaleontology 60: 557-578.

Wall-Palmer D, Smart CW, Kirby R, Hart MB, Peijnenburg KTCA, Janssen AW. 2016. A review of the ecology, palaeon- tology and distribution of atlantid heteropods (Caenogastropoda: Pterotracheoidea: Atlantidae). Journal of Molluscan Studies 82: 221-234.

Williams ST, Reid DG. 2004. Speciation and diversity on tropical rocky shores: a global phylogeny of snails of the genus Echinolittorina. Evolution 58: 2227-2251.

Received: 16 November 2015

Revised and accepted: 8 April 2016

Published online: 9 November 2016

Editor: D. Huang

\section{Online supplementary information}

S1. Collection, station and storage information for all specimens analysed in this study. * Denotes specimens used for morphometric analysis in Fig. 2. 


\section{Appendix}

Systematic descriptions

Superfamily Pterotracheoidea Rafinesque, 1814

Family Atlantidae Rang, 1829

Genus Protatlanta Tesch, 1908

Type species. Protatlanta souleyeti (Smith, 1888). Originally named Atlanta lamanoni Gray, 1850 and subsequently renamed Atlanta souleyeti by E.A. Smith.

Diagnosis. Genus of Atlantidae with an aragonite shell and a conchiolin keel. The aperture is rounded and sub-triangular in shape without a slit in the shell periphery (as in Atlanta) where the keel ends.

Description. The shell is dextrally coiled and flattened, lenticular in shape, consisting of up to $4 \frac{1}{4}$ whorls with a total shell diameter of up to $2 \mathrm{~mm}$. The spire (central, juvenile part of the shell) is slightly elevated, with incised sutures and consists of $2 \frac{1}{2}$ to $3 \frac{1}{4}$ whorls. The final adult whorl inflates rapidly and gives the shell an oval shape when viewed from the apical side. The shell is calcareous with a tall, extremely transparent and strongly truncated conchiolin keel.

Remarks. The keel of Protatlanta is extremely transparent and is often difficult to see in wet specimens. The keel in lost is fossil material, even in relatively recent sediments.

Protatlanta souleyeti (Smith, 1888)

(Fig. 5a-b, e-g, i-j)

Material examined. See supplementary Table S1.

Diagnosis. Protatlanta species with no shell ornamentation.

Description. The spire typically consists of $21 / 2$ to 3 whorls with a diameter of less than $450 \mu \mathrm{m}$. The spire has a smooth surface with no ornamentation. The shell is colourless, however the spire may vary in colour from white to dark brown due to the colour of the soft tissues (Fig. 3e-g). The complete adult shell consists of $3 \frac{1}{2}$ to $3 \frac{3}{4}$ whorls. Eyes are type a and operculum is type a (Seapy, 2011).

Remarks. Juvenile specimens are particularly difficult to identify as their lack of ornamentation and dis- tinctive features can cause confusion with juveniles of Atlanta peronii and Atlanta lesueurii. However, the aperture of juvenile $P$. souleyet $i$ is more rounded than species in the genus Atlanta.

Distribution. Distribution in the Atlantic Ocean is mainly restricted to northern and southern oligotrophic subtropical gyre regions and equatorial waters. Specimens also found in the Pacific and Indian oceans. The overall latitudinal range is between $47^{\circ} \mathrm{N}$ to $40^{\circ} \mathrm{S}$.

Protatlanta sculpta Issel, 1911

(Fig. 3c-d, h, k-l)

Material examined. See supplementary Table S1.

Diagnosis. Protatlanta species with shell ornamentation on the spire consisting of three irregular spiral lines.

Description. The spire typically consists of 3 to $3 \frac{1 / 4}{4}$ whorls with a diameter of less than $450 \mu \mathrm{m}$. The spire surface is ornamented with three spiral lines, 2 on the spire and 1 along the edge of the shell, in line with the aperture. The spiral lines are present on the second and third whorls and may be partially irregular and interrupted. Scanning electron microscopy (SEM) reveals additional finer ornamentation, including lines of pores on the first whorl and numerous fine spiral lines in the third whorl. The final, adult whorl does not have any ornamentation. The spire shell and sutures has a brown colouration, even in fossil specimens. The final adult shell consists of $3 \frac{3 / 4}{\text { to }} 41 / 4$ whorls. Eyes are type a and operculum is type a (Seapy, 2011).

Remarks. Ornamentation is similar to Atlanta gaudichaudi in the first whorls (Newman, 1990) and may cause confusion with juveniles. Atlanta plana also has similar ornamentation, however, the spire of P. sculpta is lower than that of A. plana and A gaudichaudi. Juveniles of P. sculpta have a light brown colouration.

Distribution. P. sculpta is found throughout the Atlantic Ocean from latitudes $41^{\circ} \mathrm{N}$ to $34^{\circ} \mathrm{S}$, but rarely within the northern and southern oligotrophic subtropical gyre regions. Only a single specimen was found outside of the Atlantic Ocean close to the Marquesas Islands in the south Pacific. 